\title{
Transmitting Patriarchal Voices in Aramaic: Claims of Authenticity and Reliability
}

\author{
Mika S. Pajunen
}

\section{Introduction}

The processes and mechanisms of transmitting traditions in Second Temple Judaism have from the beginning of critical scholarship been one of the focal points investigated in biblical studies. Transmission processes are indeed a complex and central issue that can be studied from a number of different perspectives and this has repercussions on more than just reconstructing the literary history of the Hebrew Bible and related literature. Classic theories concerning literary transmission, formed particularly through text- and literarycritical investigations, have been used as a methodological foundation for a plethora of individual studies. While such analyses provide much needed data on the mechanics of transmission, they cannot alone provide a full picture of the overall processes that have affected the transmission of traditions, on both theoretical and practical levels. Furthermore, the increase of source material, brought about especially by the publication of the Dead Sea Scrolls, has demonstrated the limits of the current models and methods related to textual transmission. In recent scholarship the challenge of the available empirical evidence has been taken more seriously, ${ }^{1}$ and the oral part of the transmission processes has received some much needed attention as a counterweight to the previous predominance of the literary perspective. Some scholars, such as Raymond Person, have even claimed that the transmission of traditions in Second Temple Judaism was primarily done through oral performance, thus making literary transmission only a secondary tool in the transmission process. $^{2}$ If such views were to be accepted, it would have a profound impact

1 For fresh empirically based models of transmission mechanics seeking to revise some of the more traditional methods, see, for example, Juha Pakkala, God's Word Omitted: Omissions in the Transmission of the Hebrew Bible, FRLANT 251 (Göttingen: Vandenhoeck \& Ruprecht, 2013); Juha Pakkala, Reinhard Müller, and Bas ter Haar Romeny, Evidence of Editing: Growth and Change of Texts in the Hebrew Bible, RBS 75 (Atlanta, GA: SBL, 2013).

2 For recent advances on the role of orality in the transmission processes and criticism of the traditional models, see, for example, Raymond F. Person Jr., From Conversation to Oral Tradition: A Simplest Systematics for Oral Traditions, Routledge Studies in Rhetoric and Stylistics 10 (New York: Routledge, 2016); idem, "Education and the Transmission of 
on the field of biblical studies by, for instance, marginalizing the meaning usually placed on textual variants for understanding the development of traditions as well as the historical conclusions based on such studies.

The Aramaic corpus from the Qumran caves, ${ }^{3}$ and especially the traditions connected with patriarchal figures, highlight the process of transmission as one integral element either explicitly stressed or at least more implicitly present in most of them. The transmission process itself is not typically argued for in these works. Rather, it is something the actual authors of these works take as a given and hence as a point of departure for implementing their own literary agendas and strategies. The modes of transmission and the relative importance given to them can thus reveal something about the basic processes of transmission in the society underlying these sources. Naturally, an investigation dealing only with this particular corpus will not by itself be usable as a broad theoretical basis for conclusions about transmission of traditions, but it does show how traditions were typically transmitted in the sociohistorical setting(s) of these particular authors roughly during the early and mid-Hellenistic period. ${ }^{4}$ This in turn should be taken into consideration when discussing the relative importance of the oral and literary parts of the transmission processes in late Second Temple Judaism more broadly.

When studying modes of transmission in a society underlying the surviving sources, it is necessary to make it clear when one is talking about the literary setting and when about the historical one. ${ }^{5}$ On the one hand, the references that will be brought up for closer inspection in this study naturally relate, on

Tradition," in The Wiley Blackwell Companion to Ancient Israel, ed. Susan Niditch (West Sussex: John Wiley \& Sons, 2015), 366-78; Raymond F. Person Jr. and Robert Rezetko, eds., Empirical Models Challenging Biblical Criticism, AIL 25 (Atlanta, GA: SBL, 2016).

3 For the discussion of whether the Aramaic works from Qumran constitute a distinct corpus, see, for example, Devorah Dimant, "The Qumran Aramaic Texts and the Qumran Community," in Flores Florentino: The Dead Sea Scrolls and Other Early Jewish Studies in Honour of Florentino García Martínez, ed. Anthony Hilhorst, Émile Puech, and Eibert J. C. Tigchelaar, JSJSup 122 (Leiden: Brill, 2007), 197-205; Eibert J. C. Tigchelaar, "Aramaic Texts from Qumran and the Authoritativeness of Hebrew Scriptures: Preliminary Observations," in Authoritative Scriptures in Ancient Judaism, ed. Mladen Popović, JSJSup 141 (Leiden: Brill, 2010), 155-71; Andrew B. Perrin, The Dynamics of Dream-Vision Revelation in the Aramaic Dead Sea Scrolls, JAJSup 19 (Göttingen: Vandenhoeck \& Ruprecht, 2015), 30-37.

4 The Aramaic works from Qumran are generally dated by scholars roughly to this time span; see, for example, Daniel Machiela, "Situating the Aramaic Texts from Qumran: Reconsidering Their Language and Socio-Historical Settings," in Apocalyptic Thinking in Early Judaism Engaging with John Collins' The Apocalyptic Imagination, ed. Cecilia Wassen and Sidnie White Crawford, JSJSup 182 (Leiden: Brill, 2018), 90-91.

5 For the constant need for such differentiation, see Adele Berlin, "Speakers and Scenarios: Imagining the First Temple in Second Temple Psalms (Psalms 122 and 137)," in Functions of 
the surface level, the transmission of traditions from the implied authors of the works to their implied audiences in a particular literary setting. On the other hand, the literary strategies and underlying motives for stressing specific elements in the transmission process display the agendas and basic assumptions of the actual authors in their attempts to reach and influence their actual target audiences in the historical setting. ${ }^{6}$ The study will, therefore, proceed by first examining the origins claimed for particular traditions in the literary settings of the Aramaic works and how their transmission is displayed. This analysis will highlight some common literary strategies and shared motifs that plausibly reveal concerns of the actual authors related to the transmission of traditions. The potential background of these specific similarities will then be briefly explored in the second part of this article where the emphasis is on issues related to the historical rather than the literary setting.

\section{The Origins and Transmission of Traditions}

In the following, key references pertaining to the implied origins of traditions and their further transmission in the literary settings of the Aramaic corpus from Qumran will be examined. The investigation deals particularly with the works that have a literary setting preceding Sinai because aspects related to transmission are most clearly present in them. Other works in the Aramaic corpus not pertaining to this literary setting, at least in their present state of preservation, will be brought up only when they share important elements with the principal sources of this study. As is the case with practically all of the Qumran evidence, the works in the Aramaic corpus are highly fragmentary and hence only partial evidence has been preserved. Nevertheless, the preserved portions display enough similar literary agendas that they can provide an overall picture of the way transmission processes seem to be presented in the parts

Psalms and Prayers in the Late Second Temple Period, ed. Mika Pajunen and Jeremy Penner, BZAW 486 (Berlin: de Gruyter, 2017), 341-55.

6 This terminology also relates to investigating the processes whereby a work might accrue authority as shown by the insightful study of George J. Brooke, "Authority and Authoritativeness of Scripture: Some Clues from the Dead Sea Scrolls," RevQ 100 (2012): 50723. However, this study will not deal with the question of whether some audiences in the late Second Temple period might have perceived the Aramaic works from Qumran as authoritative and in what way. It does note some issues pertinent to such a study and raises some questions related to similar issues but covers only small portions of possibly authority-related motifs in the Aramaic works, deals very little with the actual authors of the works, and hardly discusses the audiences of the works, implied or actual, which would be necessary for a comprehensive study related to the possible authority of these works in different communities. 
of the corpus containing implied patriarchal voices, even if some individual manuscripts are too fragmentary to provide enough answers on their own.

The already well-known Genesis Apocryphon that was one of the very first scrolls discovered in Cave 1 recaps some of the traditions in Genesis, ${ }^{7}$ and it is to be noted that most of the other Aramaic works discussed here also fall into this same general literary framework provided by the somewhat earlier Genesis accounts in Hebrew. This is a feature well acknowledged by scholars to which we will return later in this article. The persons claimed to have written and passed on the traditions now present in the Genesis Apocryphon are the patriarchs themselves, such as Enoch, Lamech, Noah, and Abram. Unlike Genesis, which features an "all-knowing narrator," the Genesis Apocryphon presents the traditions in it as largely first-person singular narrations of the events. This literary strategy used in the Genesis Apocryphon gives the traditions a stamp of authenticity as something actually related by the patriarchs involved in the events, rather than second-hand accounts written by someone else as the traditions in Genesis might be viewed. This kind of use of the firstperson singular as the predominant voice of the implied author(s) is true of most of the works in the Aramaic corpus from Qumran and is one of the most distinctive features of that corpus. ${ }^{8}$ The first-person accounts make it clear that this version of the tradition is intended to be perceived as a more reliable and complete form of the tradition than other already existing accounts, most significantly Genesis. Moreover, most of these works not only claim that the works are the words of the patriarchs themselves but that they furthermore contain revelations, previously unknown to the actual audiences of the work, received from God and reliably interpreted by the patriarchs. For instance, in the Genesis Apocryphon Enoch, Noah, and Abram all interpret dream oracles (for example, 1QapGen 2:20-21; 6:11-14; 19:14-21). ${ }^{9}$

The actual transmission process of diverse traditions is depicted in the Genesis Apocryphon as a primarily literary line of transmission, or at least literary works are emphasized as reliable sources that are employed in oral declaration contexts to proclaim and teach knowledge found in them. For example, Abram gives knowledge to men sent by the pharaoh by reading the words of Enoch (1QapGen 19:25) and a book of Noah is mentioned (1QapGen 5:29),

7 See Daniel Machiela, The Dead Sea Genesis Apocryphon: A New Text and Translation with Introduction and Special Treatment of Columns 13-17 (Leiden: Brill, 2015).

8 See, for instance, Devorah Dimant, "Themes and Genres in the Aramaic Texts from Qumran," in Aramaica Qumranica: Proceedings of the Conference on the Aramaic Texts from Qumran in Aix-en-Provence 3o June-2 July 20o8, ed. Katell Berthelot and Daniel Stökl Ben Ezra, STDJ 94 (Leiden: Brill, 2010), 15-45; Machiela, "Situating the Aramaic Texts," 91.

9 See further Perrin, The Dynamics of Dream-Vision Revelation, 52-57, 128-43. 
apparently as the title for the subsequent first-person singular account of Noah. Unfortunately, the very beginning of the Genesis Apocryphon is now lost and it cannot be known whether it contained references to the transmission of the work itself as is the case with the Testament of Qahat and Visions of Amram discussed below. Nevertheless, the literary form of Genesis Apocryphon itself also seems to point to the perceived reliability of this mode of communication.

Another work presented in a first-person singular voice, the Testament of Qahat (4Q542), ${ }^{10}$ contains teaching and admonitions related as Qahat's words to his offspring, the priestly and Levitical lines. It also claims to contain traditions that were previously passed down in literary form to Qahat from his father Levi (4Q542 1 ii 9-13). ${ }^{11}$ The text admonishes the audience to heed laws and deeds that are related to Abraham, Jacob, Levi, and Qahat himself ${ }_{4} Q_{542}$ 1 i $7-12$ ). Thus, the patriarchs are again emphasized as trustworthy originators of the traditions presented in the work. This time the patriarchs are credited as sources of knowledge, ethics, and regulations to be heeded. The preserved part of the text apparently contains part of a foreword written by Qahat for the following literary traditions presented as deriving from Levi that Qahat now in turn passes on to the care of his son Amram and the next generations in the Levitical line.

Literary traditions are thus once more given pride of place and used to claim reliability for the message of the rest of the work that is unfortunately now lost. Both Levi and Qahat are used as the implied authorial voices of the work but the authenticity of these voices is further guaranteed by the mode of literary transmission and enhanced by the notion that the literary tradition has already been reliably passed on from Levi to Qahat and will continue to be transmitted faithfully by all the subsequent generations of Levites. The stress placed on the authenticity and reliable transmission of the tradition seems to presuppose the ideal concerning the immutability of texts that is claimed in many works, such as Deuteronomy (Deut 4:2; 13:1), the Temple Scroll $\left(11 \mathrm{QT}^{\mathrm{a}}\right.$ 54:5-7), and by Josephus (Ant.1.17). As is well evidenced in the preserved literature from this period, in practice this ideal was not really honored by authors and editors, including the authors of the above passages. Nevertheless, the idea that literary traditions would be more reliable and stable than oral ones seems to have been present and underscored by at least some authors in

10 See Émile Puech, Qumran Grotte 4.XXII:Textes araméens, première partie:4Q529-549, DJD 31 (Oxford: Clarendon Press, 2001), 257-82.

11 The emphasis placed on the written form of the tradition in the Testament of Qahat, Aramaic Levi Document, and Visions of Amram has also been observed by Dimant, "Themes and Genres," 29-32. 
the Second Temple period and it appears to have been further used as a way of convincing people about the authenticity of particular traditions.

As a third example, the so-called Birth of Noah text $\left(4 \mathrm{Q}_{534-536)^{12}}\right.$ is once more presented at least partly as the actual words of an authorial figure and it also displays other literary works as important sources of reliable knowledge. In 4 Q534 $1 \mathrm{i} 5$, three books are mentioned that a person is to learn in order to become wise. These are obviously literary traditions, and, as the father and forefathers of the implied author are mentioned next in the text, it seems these three literary works are related by the chronologically preceding patriarchs to the main authorial voice in much the same way as in the Testament of Qahat. These earlier literary traditions supposedly teach "secrets" of the universe, and the implied author of this work is presented as a transmitter of such secrets (4Q534 1 i 6-11; 2 i 8-13). In 4Q536 2 ii 12-13 further emphasis is placed on the value of literary traditions as it speaks about writing the "I" narrator's words in a book, which the composition itself obviously does. Thus, once more a scene of an oral declaration written down by the person receiving the revelation is depicted as the original source of the Aramaic literary tradition, guaranteeing its authenticity. Whether or not the words ever actually were transmitted orally before being written down is doubtful in this case, but it is important to note that the writing down and passing on of oral declarations in a literary form is seen as an occasion of solidifying the tradition and making it, or rather claiming it to be, more reliable than a purely oral tradition.

This basic picture of transmission found in the above three examples seems to be shared by a great number of the Aramaic texts. There is frequently an authorial "I" that is typically identified with a patriarch. This "I" then recounts events related to himself and his life or traditions supposedly passed down by the previous patriarchs in a direct line of succession, admonitions meant to be followed, and/or interpretations of visions allegedly seen by the implied author that are associated with the future or heavenly matters otherwise unapproachable by humans. It is quite typically emphasized in these works that the words are now in literary form, even if an oral declaration setting is given as the first occasion for the unveiling of the revelation in question. Such features are present, for example, in the Aramaic Levi Document (1Q21, 4Q213-214), ${ }^{13}$ which mentions other literary works (4Q213 2 9; 4Q214a 2-3 ii 5) and contains

\footnotetext{
12 See Puech, DJD 31:117-70.

13 For the official editions, see, Józef T. Milik, “21. Testament de Lévi," in Qumran Cave 1, ed. Dominique Barthélemy and Józef T. Milik, DJD 1 (Oxford: Clarendon Press, 1955), 87-90; Michael Stone and Jonas Greenfield, "Levi Aramaic Document," in Qumran Cave 4.XVII: Parabiblical Texts, Part 3, ed. George J. Brooke et al., DJD 22 (Oxford: Clarendon Press, 1996), 1-72.
} 
revelations shown to the implied author of the work, Levi, in a literary form. Furthermore, if the larger framework of the Aramaic Levi Document, not preserved in the Qumran Levi material, is taken into account, further clues concerning the implied transmission of this tradition are found. On the whole, the traditions in the Aramaic Levi Document are presented as transmitted to Levi by the previous patriarchs and through him to the care of the Levitical line, making them the further transmitters of this literary heritage. The regulations concerning proper sacrifices are, for instance, according to the Aramaic Levi Document given to Levi by Isaac who in turn was instructed by Abraham in accordance with the Book of Noah. ${ }^{14}$ While the tradition seems to have been passed on orally from Abraham to Isaac and then to Levi, a literary transmission is claimed to have both preceded and followed this phase. The implied origins and subsequent chain of custody for this particular tradition are thus made abundantly clear and were seemingly a matter of importance for the actual author of the work. The overall emphasis placed on the authentic origins of the traditions in the Aramaic Levi Document and on its reliable literary transmission to future generations is quite similar to that found in the Testament of Qahat, and once more the medium used to transmit the tradition from earlier patriarchal times to future generations is Levi and his descendants.

Agendas similar to these are also visible in other Aramaic works dealing with the antediluvian and patriarchal periods. The books of Enoch and the related traditions in the Book of Giants (1Q23-24, 2Q26, 4Q201-212, 4Q530-533, 6Q8) feature visions interpreted by Enoch himself and events supposedly witnessed by him, ${ }^{15}$ and mention is made of an announcement of revelations by Enoch that he himself has written down (4Q203 8 3-4; cf. 4Q204 1 vi 9 and 19). Enoch is also said to have seen the future as written reliably on heavenly tablets and passed the tradition on to his descendants (4Q204 5 ii 26-27; 4Q212 1 ii 22-24; 4Q212 1 iii 21-23). Words of Michael $\left(4 \mathrm{Q}_{529}\right)^{16}$ is also a first-person singular

14 See further Henryk Drawnel, An Aramaic Wisdom Text from Qumran: A New Interpretation of the Levi Document, JSJSup 86 (Leiden: Brill, 2004), 80-81.

15 For text editions of these manuscripts, see especially, Loren T. Stuckenbruck, The Book of Giants from Qumran: Texts, Translation and Commentary, TSAJ 63 (Tübingen: Mohr Siebeck, 1997): idem, "201. 4QEnoch", 203.4QEnoch Giants" ar, 206. 2-3.4QEnoch ${ }^{\mathrm{f}}$ ar, 1Q23. 1QEnochGiants ${ }^{\mathrm{a}}$ ar, 1Q24. 1QEnochGiants ${ }^{\mathrm{b}}$ ? ar 2Q27. 2QEnochGiants ar, 6QpapGiants ar," in Qumran Cave 4.XXVI: Cryptic Texts, and Miscellanea, Part 1, ed. Stephen Pfann (cryptic texts), Philip Alexander et al. (miscellania), DJD 36 (Oxford: Clarendon Press, 200o), 3-94; Eibert J. C. Tigchelaar and Florentino García Martínez, "208-209. 4QAstronomical Enoch $^{\mathrm{a}-\mathrm{b}}$ ar," in Qumran Cave 4.XXVI: Cryptic Texts, and Miscellanea, Part 1, ed. Stephen Pfann (cryptic texts), Philip Alexander et al. (miscellania), DJD 36 (Oxford: Clarendon Press, 2000), 95-171; Puech, DJD 31:9-116.

See Puech, DJD 31:1-8. 
narrative where the written form of the work is emphasized at the very beginning, which introduces the work as the words of the Book of Michael that he told the angels (4Q52911), and it also speaks about what is written in the book of the great eternal lord (4Q529 16 ). "I" speakers and writing on scrolls or tablets are also mentioned in the more fragmentary testamentary material, such as $4 \mathrm{Q}_{537}$, which features a revelation on heavenly tablets disclosing the future to the implied author, who is apparently Jacob (4Q537 1-3 3-5), and in 4Q541, where the implied author is depicted as studying previously hidden written revelations (4Q541 7), in turn exhorting his implied audience to study the given written revelation carefully in order to know what will happen, but to be careful not to damage the scrolls (4Q541 24 ii 3-4).17

A final work in the Qumran Aramaic corpus dealing with the patriarchs that deserves a separate mention is Visions of Amram. ${ }^{18}$ In the opening line, the work is presented explicitly as "a copy of the book, the words and visions of Amram" containing all he declared and commanded to his sons Moses and Aaron (4Q543 11-2). Again, at least a partly oral declaration is claimed to have been written down, apparently by the "I" speaker himself who is explicitly depicted in 4Q547 9 8-9 as seeing a vision and writing it down (cf. 4Q545 4 15-16; 4Q549 2 6). ${ }^{19}$ In light of the similar agendas found in the examples just given, a wording similar to the one at the beginning of the Visions of Amram could probably be applied to most of these Aramaic works dealing with the patriarchs, just replacing Amram with the other patriarchal voices used. In practical terms, from the point of view of the literary setting, it is of course necessary in order for the purported visions to be truthfully and reliably transmitted that they are either written down or otherwise directly related by the person who experienced them because only these specific individuals are allowed to see them, let alone interpret them correctly. And this is something that most of the Qumran Aramaic texts dealing with the patriarchs are very careful to do; they explicitly describe the alleged origin of the tradition and the chain of custody through which it ended up in the current work. Hence, by the aid of carefully chosen literary strategies, these traditions are presented

17 For the editions of the manuscripts, see Puech, DJD 31:171-90, 213-56. The New Jerusalem texts $\left(\mathrm{1}_{32}, 2 \mathrm{Q}_{24}, 4 \mathrm{Q}_{554}, 4 \mathrm{Q}_{554} \mathrm{a}, 4 \mathrm{Q}_{555}, 5 \mathrm{Q} 15\right.$, and $\left.{ }_{11} \mathrm{Q}_{18}\right)$ are somewhat distinct in form from these other works and the speaker is not identified in the preserved text, but it is nevertheless another first-person visionary experience that might be connected with a patriarch.

18 See Puech, DJD 31:283-406.

19 See also Henryk Drawnel, "The Initial Narrative of the Visions of Amram and Its Literary Characteristics," $\operatorname{RevQ} 96$ (2010): 517-54 (527). 
to their actual Second Temple audiences as authentic accounts that have been transmitted reliably in written form from the beginning.

To make it clear, it is not claimed here that all of these Aramaic texts should be indiscriminately grouped together; on the contrary, they should continue to be studied both separately and as a corpus containing diverse material. But nevertheless, there are some significant similarities in them, especially concerning the literary devices employed, that should be investigated as common literary strategies, whether employed by the same circles or by different groups of authors successively imitating previous works. Some of these similarities have already been quite extensively studied by scholars, and it is far beyond the scope of the present investigation to deal with all of them, but several of the similarities seem elemental for perceiving the motives behind the emphasis placed on the origin and transmission of these traditions. These will be briefly taken up in the following. One of these features is the often encountered authorial "I" that is rare in Hebrew works except for words of God and the voices of most psalmists. As always, there are some other exceptions, especially in poetic works, but overall there does seem to be a marked difference between the Hebrew and Aramaic works in this respect. Furthermore, if a comparison is made between the Aramaic narratives and Hebrew narrative works, the difference is much more distinctive. Another significant similarity in the Aramaic corpus from Qumran is the chosen literary setting, which is predominantly pre-Sinai. Only the Aramaic Tobit and Daniel traditions are clear exceptions in both these respects. They are set in the exilic period and hence presume Sinai rather than precede it, and both of them are mostly third person accounts of the events. Daniel does see visions and they are sealed in a book and the priestly lineage is present in $4 Q_{245} 1$ i 4-12, where the list of high priests is preceded by a notion of a literary work. However, regardless of these few similarities, the Daniel and Tobit traditions are in overall terms quite different from the other Aramaic works discussed here, and will thus not be investigated further in this study.

An obvious similarity that is shared by all these works, and which is of course the main reason they were originally grouped together, is the Aramaic language. It is debated whether the choice of Aramaic over Hebrew is to be related to the literary settings used in these works, as a way of further strengthening their claims for authenticity, or to the sociohistorical setting of the actual authors. This is a complex question that should be discussed separately for each of the Aramaic works, as far as possible, and the answer may not be either/or in each case. Because of the other shared literary strategies in these works it seems plausible that the language may at least have served 
as yet another tool for making the literary setting appear more authentic. ${ }^{20}$ If Hebrew as a language was revealed only at Sinai to Moses, as some may have believed in the late Second Temple period, ${ }^{21}$ then logically the pre-Sinai people had to have spoken some other language. A notion of the patriarchs as wandering Arameans (Deut 26:5) may have played into this language choice as well, or perhaps Aramaic as a widely spread Semitic language in official use at the time these Aramaic works were written was seen as a plausible lingua franca of the pre-flood people passed down to subsequent generations through Noah and his sons. ${ }^{22}$ Be that as it may, the practical reason for writing in Aramaic could have been that if the language of the patriarchs was not yet Hebrew then Aramaic was a language at least equally understandable by the target audiences and could be presented to them as a plausible alternative for Hebrew in literary settings where Hebrew would not be the expected language. Most of the works in Aramaic from Qumran seem to deal with people living at a preSinai time or in a foreign country and speaking with foreigners, ${ }^{23}$ which does imply that some of the actual authors of these works may have used Aramaic consciously to try and paint a more authentic scene of the events to their audiences. ${ }^{24}$ But it could also be that sometimes the selected language and terminology additionally reflect choices necessitated by the actual author's own sociohistorical setting and aim to reach more people, even abroad. ${ }^{25}$ Of course, these are not mutually exclusive alternatives; for example, the use of more general divine epithets, such as "God Most High" (אל מל עליון) rather than "God of Israel" (אלהי ישראל) can be argued to relate to the real sociopolitical international setting the work was aimed at, or to have been chosen because of

20 Dimant, "The Qumran Aramaic Texts," 203, astutely notes the paucity of Aramaic works that would pertain to the period from Moses to the end of the kingdom of Judah as well as to the prophets connected with these periods.

21 For some possible sources pointing in this direction, see Jonathan Ben-Dov, "Hebrew and Aramaic Writing in the Pseudepigrapha and the Qumran Scrolls: The Ancient Near Eastern Background and the Quest for a Written Authority," Tarbiz 78 (2009): 27-6o (in Hebrew).

22 For Aramaic as a lingua franca in the Levant during the approximate period the Aramaic corpus was written, see Machiela, "Situating the Aramaic Texts," 101-102. When a language has such a position in the historical setting of the actual authors, it is easy, and probably even plausible to the actual audience of the works, to project a similar situation backwards in time to the imaginary literary settings as well.

23 For the predominance of these two literary settings in the Aramaic corpus from Qumran, see Dimant, "The Qumran Aramaic Texts," 197-205; "Themes and Genres," 15-45.

24 For the use of Aramaic as primarily instigated by concerns related to the literary settings of the works, see, for example, Dimant, "The Qumran Aramaic Texts," 204; Ben-Dov, "Hebrew and Aramaic Writing," 27-6o.

See especially Machiela, "Situating the Aramaic Texts," 88-109. 
a literary setting preceding the exodus, which is when God explicitly becomes the God of Israel, ${ }^{26}$ or both kinds of motives may have played a part in the choice of terminology.

Intriguing in terms of this choice of language is Jubilees, which seems to intentionally pit itself against the Aramaic traditions concerning the patriarchs at least slightly predating it by endorsing the authentic nature of the Hebrew traditions concerning the patriarchs, and hence also its own reinterpretation of them. It not only enforces the Mosaic, Sinai-centered origins for the accounts concerning the primordial and patriarchal times, but also explicitly states that Hebrew was the language of creation and was taught by an angel to Abraham, who then studied literary works written by his forefathers that are again emphatically claimed to have been in Hebrew (Jub. 12:26-27). This emphasis on Hebrew is probably partly a move instigated by changes in the social setting of the actual authors but it is also a rather direct statement against the claims for authenticity of works written as first-person accounts in Aramaic, such as, the Genesis Apocryphon. ${ }^{27}$ Furthermore, it implies that at least the author(s) of Jubilees took the language choice between Hebrew and Aramaic as a strategy pertaining to the authenticity of a tradition, the Aramaic patriarchal voices against the Hebrew ones, choosing to defend the authenticity of the latter over against the former. Naturally this only tells us about the possible way in which the author of Jubilees may have interpreted the matter, not about why the actual authors of the Aramaic corpus originally made the language choice. But it is a sign of how the language choice may have been perceived by some authors around the middle of the second century все. While the use of Aramaic at least as a literary strategy thus seems likely, the least that can be said is that the choice of Aramaic over Hebrew seems to be connected with the international setting of these works, be it literary, historical, or both.

All the literary strategies discussed above pertain to the claims of authenticity and reliability of the patriarchal traditions in Aramaic and this also appears to be the motive for highlighting the transmission of traditions in many of these works. It is clear on the basis of the above survey that the literary medium was regarded by the actual authors of these works as giving their works a further cachet of authenticity and reliability. Even in the preserved sections many of the works state that they were written by the implied authors themselves, and further literary works, by preceding patriarchs or in the form

26 The epithet is used for the first time by Moses in Exod 5:1.

27 For a more thorough analysis regarding the Jubilees passage and Jubilees as a whole in connection with the patriarchal voices in Aramaic, see Ben-Dov, "Hebrew and Aramaic Writing," 27-6o. 
of heavenly records, are sometimes presented as the basis of parts of the current literary work. It is also frequently asserted who were designated as the custodians and transmitters of the literary work after it left the hands of the implied author. Thus, the primary position given to the written record in these works is quite evident and it would seem an odd literary strategy if a similar value was not placed on written works in the underlying society of the early to mid Hellenistic period.

The role of the oral component in the transmission process is much harder to decipher in these works because of the marked emphasis placed on written traditions. It seems that in the literary setting of at least some of these works an oral component is part of a new interpretation given to prior literary works before the interpretation itself in turn becomes a part of the stream of literary traditions. For example, the tradition concerning sacrifices in the Aramaic Levi Document discussed above seems to go through a period of oral interpretation. The tradition is said to be based on a Book of Noah, but this book is not directly passed on to Levi. Rather, Abraham teaches the regulations to Isaac in accordance with this book, and Isaac, in turn, orally instructs Levi. This oral phase of the tradition seems to be based on the Book of Noah but interpreting it further while at the same time being generally in accordance with it. The oral teaching of Isaac is then again placed in written form by Levi and transmitted to future generations. Similarly, in the so-called Birth of Noah texts, the implied author is said to possess three prior literary works teaching secrets of the universe, but it is not stated that the so-called Birth of Noah is to reproduce these works but rather to contain the words of the implied author concerning the issues covered in these prior works, and the same can be said about the relation of the Enochic traditions to the heavenly tablets (cf. 4Q529 and 4Q537), and that of the Testament of Qahat to the traditions from Levi that Qahat claims to have received in written form. In all these cases one or more written records, presented as reliable works on their own, are depicted as a partial basis for the oral declaration and further interpretation of such traditions presented in the voice of the implied author, which are moreover typically enhanced by further divine revelations only accessible to the implied author. This fresh revelation and interpretation is then written down in turn, usually by the implied author himself.

Such fresh written works, containing both interpretation of some prior traditions as well as new revelations, also claim a legitimacy and authenticity for the interpretation of specific traditions perhaps lacking before. The so-called Fortschreibung technique used in the transmission of literary works, at least during the early Second Temple period, of course places later interpretive elements as parts of the prior literary work itself, but the Aramaic texts mostly 
seem to represent a slightly different, and perhaps later, scenario where the tradition in written form and its oral interpretation are more often consecutive phases that result in the creation of further literary works, not in the direct editing of the interpreted literary work itself. For the most part these Aramaic works dealing with the patriarchs seem to be meant to exist alongside prior works, not as direct replacements for them. They claim to offer a more reliable and authentic account of some events, but also completely new divine revelations and historical details complementing the previously existing traditions. As literary traditions, the content of these Aramaic works would then likely be viewed in such a sociohistorical setting as open to subsequent oral interpretations but at the same time these already written traditions would continue to be transmitted to further generations. The model of transmission in at least some of the Aramaic works from Qumran appears, thus, to be cyclical, alternating between written tradition and its oral explication that forms the basis for further literary works, and so forth. The written tradition seems to be the more prominent and stable ingredient in the process whereas the oral component serves as an actualization of the message of the written works in changing times and settings. These are then in turn written down and serve once more as a basis for fresh oral interpretation. This mode of transmission seeks to simultaneously ensure the relative stability of the tradition through its relative faithfulness to the written basis and its potential to answer ever changing questions and problematic issues in the traditions through oral interpretation that is then written down in turn as another seemingly authentic revelation and enters the stream of literary traditions. ${ }^{28}$ Thus, at least some of the Aramaic works from Qumran seem to be situated roughly in the middle of a trajectory concerning the explicitness of the interpretation of a tradition. At one end would be the kind of scene depicted in Neh 8:8-9 where the written tradition is read and subsequently orally interpreted for the people but the oral interpretation is not said to be written down. On the other end stand the commentary works from the late Second Temple period, such as the pesharim, where the base text and its interpretation are both written down in the same document, ensuring that the "correct" interpretation is also preserved in writing together with the source text, but already clearly separated from one another. Due to the fragmentary state of the material, it cannot be said whether all the discussed

28 If true, this kind of general attitude towards literary works would in time result in a great number of diverse literary works claiming to be representatives of a specific larger tradition, all of which would continue to be copied to further generations, and, incidentally, this kind of textual plurality is evident in the collection of texts preserved in the Qumran caves. 
Aramaic works subscribe to a similar process of transmission but it seems that in general they depict the literary form of traditions as the more reliable one, and hence the remaining uncertainty relates most of all to the importance and place of the oral aspect of the transmission processes at the time when these works were written.

\section{Compositional Agendas Related to Transmission Processes}

It can be concluded from the previous discussion that the actual authors of the Aramaic works, speaking with implied patriarchal voices, used a number of similar literary strategies that served particularly to highlight the authenticity and reliability of their works. Therefore, it needs to be asked, authenticity and reliability in relation to what? For the answer to this question the literary setting chosen by the actual authors seems to be highly significant because almost all of the Aramaic works found at Qumran are set in a pre-Sinai period. The revelation at Sinai and its basic content is clearly not questioned in these works; according to the exodus traditions, the laws there were given by God, and even though they need further practical interpretation, the written form of the revelation there seems to have become close to unalterable at the time the Aramaic works were written. Most works in the late Second Temple period do not even try to challenge the general content of the Sinai revelation any more, the possible exception, depending on its dating, being the Temple Scroll. The law was thus given by God through Moses at Sinai, but a more pertinent question for these late Second Temple period authors seems to have been, where did the traditions in Genesis originate? Nothing in the text of Genesis indicates who the authority is that would guarantee the accuracy of the Genesis accounts, i.e., what is the identity of the "all-knowing narrator"? This readily perceivable gap in the Genesis accounts is probably one central reason for the stress placed in the Aramaic works on the authentic origin of their own works and on their subsequent reliable transmission. As a contrast to Genesis, these works are supposed to be seen as authentic first-person accounts of the patriarchs, and great care has been taken by the actual authors of these works to make them appear as genuine as possible. The patriarchal works in Aramaic thus claim to give a fuller and more reliable picture of the events than Genesis alone, and even to supplement the revelation at Sinai by already pre-Sinaitic revelatory traditions. And by claiming that these revelations contain especially cosmological knowledge and details about the future, not dealt with in the Sinai revelation, these Aramaic works claim to reveal the basic mechanisms 
of how the world works and the theological principles guiding it from the very beginning as well as prophetic knowledge concerning the coming days.

This strategy of placing significant revelations already in the patriarchal period somewhat decentralizes Sinai or perhaps rather puts it on a continuum of noteworthy revelations that began long before Sinai, which is consequently no longer seen as the climax towards which everything points. That the murky origins of Genesis traditions seem to have been a gap to be exploited is also demonstrated by Jubilees, which gives its own interpretation of the pre-Sinai events but cleverly presents it as heavenly revelation written on tablets in Hebrew and revealed to Moses at Sinai. Hence in Jubilees Moses saw not only the future but also the past by receiving authentic and reliably transmitted knowledge of it from the angels and writing it down (Jub. 1:4-7, 26-28). It is noteworthy that in Jubilees too the literary nature of the transmitted traditions is emphasized as well as the heavenly and Mosaic transmitters of it. Thus, while the revelation at Sinai was largely set by the late Hellenistic period, the traditions preceding it could apparently still be augmented or could even be contradicted, particularly concerning the origins of evil and knowledge that had become more central theological concerns in the late Second Temple period. The use of the authorial "I" and the emphasis placed on the origin and transmission of the traditions in the Aramaic works related to the patriarchs and Jubilees seem to be deliberate strategies to exploit this void left in Genesis without leaving a similar gap open concerning the authenticity and reliability of the traditions presented in them.

A final element present in many of the Aramaic works that pertains to transmission is an emphasis on the priestly and Levitical lines and their central role in transmitting the traditions. Whether this is just another literary strategy or is also to be seen as evidence for priests and Levites as the actual authors of these particular Aramaic works is debatable. The place of Levites as key agents in the transmission of traditions during the Second Temple period has been theorized by many scholars, such as David Carr, ${ }^{29}$ but only a few remarks, mostly concerning the Aramaic corpus, can be made about it in the scope of this study. The emphasis on the line of Levi as trustworthy tradents in some of the Aramaic works, such as the Testament of Qahat, the Aramaic Levi Document, and the Visions of Amram, is certainly tantalizing. Similarly the role given to the Levites in Neh 8:8-9 as oral interpreters of the written law certainly depicts them as reliable interpreters of the law, but in the Aramaic corpus it seems the

29 David Carr, Writing on the Tablet of the Heart: Origins of Scripture and Literature (Oxford: Oxford University Press, 2005). 
intention is to give such Levitical interpretation of traditions preceding Sinai roots as authentic literary traditions on their own, revealed to members of the Levitical line and passed on faithfully.

Whether this means the actual authors of these Aramaic works were priests and Levites, or whether the authors just used a societal perception of Levites as trustworthy interpreters as one more literary element giving their own message a further stamp of reliability, cannot be conclusively decided in this study. In my view, it is most likely that at least some of these Aramaic works were actually written by priestly or Levitical circles, but nevertheless a word of caution is in order to emphasize the need to continue the careful study of each individual document before making broader conclusions regarding the whole corpus concerning this question. After all, late Second Temple authors clearly retained the ability to employ, for instance, Deuteronomistic theology and vocabulary in their works in order to give them more legitimacy, ${ }^{30}$ and to imitate earlier poetic styles as evinced by the different versions of Psalms 151 and 154. Furthermore, from the standpoint of transmission, if the claims of authenticity and reliability in the Aramaic works were to be taken seriously by their contemporaries, who could the actual authors use in the literary settings they had chosen as plausible mediators for transmitting their works through the centuries in a direct line of succession, except the priestly and Levitical lines? From a Second Temple perspective, there are no other genealogical lines reaching as far back that would, as a group, continually have the necessary skills to pass down literary traditions as well. Furthermore, it seems that a similar motive for emphasizing the priestly/Levitical background of a mediator is to be found at least in the afterword to Lxx Esther (Add Esth F:11). Regardless of whether the information is historically accurate, the author of the afterword has chosen to emphasize that the one transmitting the translated work to Egypt and guaranteeing its authenticity was both a priest and a Levite. This is not a claim made about a priest or a Levite writing the Book of Esther, or even translating it, but ensuring its reliable transmission to the target audience. In light of this kind of role assigned to priests and Levites as caretakers of traditions it has to be questioned whether every work emphasizing them as transmitters of traditions can also be attributed to them.

There certainly are works in the Aramaic corpus that do seem to contain additional motifs commonly associated with priests, such as sacrifices, purity

30 Juha Pakkala, Marko Marttila, and Hanne von Weissenberg, eds., Changes in Scripture: Rewriting and Interpreting Authoritative Traditions in the Second Temple Period, BZAW 419 (Berlin: de Gruyter, 2011). 
concerns, and priests as ideal figures, ${ }^{31}$ as well as elements of what has often been deemed a priestly style of writing, such as the extensive use of different kinds of lists. However, each of these works should continue to be assessed separately before drawing conclusions about a potentially shared social milieu of all the writers. After all, many of these Aramaic works also employ other kinds of motifs not as commonly associated with priestly circles, such as wisdom elements and prophetic/apocalyptic discourse. ${ }^{32}$ Moreover, it is well evidenced that these different perspectives become more and more intertwined in works written in the late Second Temple period, which would tend to make the identification of the actual writing circles even more difficult than before. For this investigation it is enough to conclude that whether or not the actual writers were priests or Levites the use of these particular family lines as a guarantee of the trustworthy transmission of literary traditions would probably have lent further credibility to the claims of authenticity and reliability made by the actual authors of the works, whoever they were.

This brief investigation of the transmission of traditions in the Aramaic texts from Qumran revealed some significant elements present in many of the Aramaic texts that seem to be best labeled as literary strategies intended to highlight the ancestry, origin, and reliability of the written works in question. The literary settings used in these works and the figures central to them show that the origins of the traditions now found in Genesis were not clear and allowed late Second Temple period authors to try to augment them with their own interpretations of events and fresh revelatory material. At the same time, these authors sought to provide their audiences with further allegedly divine knowledge by using the voices of the same mediators from the pre-Sinai past that had been established as noteworthy and trustworthy figures by the Genesis traditions. It would appear that this was done in most cases in order to

31 See, for example, the analysis of priestly concerns in the Aramaic Levi Document by Drawnel, An Aramaic Wisdom Text from Qumran, 61-63, and a survey of some facets of priestly theology in the Aramaic texts featuring dream visions by Perrin, The Dynamics of Dream-Vision Revelation, 158-89.

32 For a useful survey of the apocalyptic elements in the Aramaic corpus from Qumran, see Daniel Machiela, "Aramaic Writings of the Second Temple Period and the Growth of Apocalyptic Thought: Another Survey of the Texts," Judaïme ancien/Ancient Judaism 2 (2014): 113-34. For the place of the Aramaic works in revelatory prophetic literature more broadly, see Perrin, The Dynamics of Dream-Vision Revelation. 
solidify certain interpretations, practices, and theological views as the correct ones, carefully transmitted from patriarchal times to the contemporary audiences. A similar move was made in the early Hellenistic period by Chronicles in grounding the contemporary liturgical practices in King David's time and figure. But the authors of many of the Aramaic works extended the timeline of various Second Temple practices and beliefs even further back in time, into primeval and patriarchal periods. As a byproduct of this activity Sinai seems to have lost some of its revelatory centrality, as there were cosmologically and theologically more relevant revelations preceding it. Instead of being the central event, Sinai becomes one of several main revelatory traditions preserved in writing, Jubilees providing the obvious exception where the revelation at Sinai is practically claimed as the basis for all knowledge concerning events preceding it as well.

And at least sometimes, groups in the late Second Temple period shifted their emphasis on matters to pre-Sinai events through this gate opened up especially by the Aramaic works. For instance, it seems that in the liturgical works of the yahad community the more priest-centered and Mosaiccovenant-remembering traditions were at some point at least partly replaced by a cosmological union of chosen humans and angels representing the whole creation with the evil forces led by Belial as their opposition. Liturgy from creation onwards, instead of from Sinai or David, allows for the incorporation of a more general liturgical communion than a priestly-led one as well as the integration of a cosmological worldview of good and evil instead of Israel and the nations. Liturgy, wisdom, and knowledge, perhaps embodied in the yahad most fully by the office of the maskil, had, according to most available late Second Temple works dealing with these questions, all been there since the creation of the world. Hence their correct application could be seen as demonstrating a claim to have grasped God's purpose for humankind from the creation onwards. This kind of reevaluation of the significance of pre-Sinai events and traditions is the driving force behind several other theological innovations of the era. For example, Paul goes back in time beyond Sinai when he needs to explain the inclusion of the gentiles in the covenant. He goes back to Abraham, who seems to provide a suitable model for his thinking. These kinds of interpretations are the fruits of works like those dealt with in this study. They provided a basis and means for some groups to claim that their interpretation of traditions and practices preceded Sinai, and hence opened the door for interpretations where Sinai becomes more secondary in order for central theological notions of a group to be "verified."

Finally, to return briefly to the technical process of transmission, it seems that both oral and written components of transmission are presumed to exist 
in the literary setting of the Aramaic works containing patriarchal traditions, but literary traditions are presented as much more central and are used as reliable anchors from which an oral interpretation of the tradition can be derived and in turn be turned into literature. The importance and value of literary works are further propagated as a way of trying to enhance the authenticity and reliability of the authors' own works, which implies that they were perceived by the writers as a more convincing medium for claims related to transmission of a tradition than purely oral transmission. Nevertheless, it needs to be stressed again that this study has only worked with one corpus of literature stemming from a specific time period, and by investigating how the wider transmission processes are presented in these works. For instance, nothing has been said about how the authors used their own source material, such as Genesis, in practice, and Hebrew works from the same general time period should also be investigated as comparative material in order to more fully discuss whether the image deduced from the Aramaic material concerning transmission processes is related to a particular circle of writers or is representative of larger societal practices.

\section{Bibliography}

Ben-Dov, Jonathan. "Hebrew and Aramaic Writing in the Pseudepigrapha and the Qumran Scrolls: The Ancient Near Eastern Background and the Quest for a Written Authority." Tarbiz 78 (2009): 27-6o (in Hebrew).

Berlin, Adele. "Speakers and Scenarios: Imagining the First Temple in Second Temple Psalms (Psalms 122 and 137)." Pages 341-55 in Functions of Psalms and Prayers in the Late Second Temple Period. Edited by Mika Pajunen and Jeremy Penner. BZAW 486. Berlin: de Gruyter, 2017.

Brooke, George J. "Authority and Authoritativeness of Scripture: Some Clues from the Dead Sea Scrolls." RevQ 100 (2012): 507-23.

Carr, David. Writing on the Tablet of the Heart: Origins of Scripture and Literature. Oxford: Oxford University Press, 2005.

Dimant, Devorah. "The Qumran Aramaic Texts and the Qumran Community." Pages 197-205 in Flores Florentino: The Dead Sea Scrolls and Other Early Jewish Studies in Honour of Florentino García Martínez. Edited by Anthony Hilhorst, Émile Puech, and Eibert J. C. Tigchelaar. JSJSup 122. Leiden: Brill, 2007.

Dimant, Devorah. "Themes and Genres in the Aramaic Texts from Qumran." Pages 15-45 in Aramaica Qumranica: Proceedings of the Conference on the Aramaic Texts from Qumran in Aix-en-Provence 30 June-2 July 2008. Edited by Katell Berthelot and Daniel Stökl Ben Ezra. ST DJ 94. Leiden: Brill, 2010. 
Drawnel, Henryk. An Aramaic Wisdom Text from Qumran: A New Interpretation of the Levi Document. JSJSup 86. Leiden: Brill, 2004.

Drawnel, Henryk. "The Initial Narrative of the Visions of Amram and Its Literary Characteristics." RevQ 96 (2010): 517-54.

Machiela, Daniel. "Aramaic Writings of the Second Temple Period and the Growth of Apocalyptic Thought: Another Survey of the Texts." Judaïsme ancien/Ancient Judaism 2 (2014): 113-34.

Machiela, Daniel. The Dead Sea Genesis Apocryphon: A New Text and Translation with Introduction and Special Treatment of Columns 13-17. Leiden: Brill, 2015.

Machiela, Daniel. "Situating the Aramaic Texts from Qumran: Reconsidering Their Language and Socio-Historical Settings." Pages 88-109 in Apocalyptic Thinking in Early Judaism Engaging with John Collins' The Apocalyptic Imagination. Edited by Cecilia Wassén and Sidnie White Crawford. JSJSup 182. Leiden: Brill, 2018.

Milik, Józef T. “21. Testament de Lévi.” Pages 87-90 in Qumran Cave 1. Edited by Dominique Barthélemy and Józef T. Milik. DJD 1. Oxford: Clarendon Press, 1955.

Pakkala, Juha. God's Word Omitted: Omissions in the Transmission of the Hebrew Bible. FRLANT 251. Göttingen: Vandenhoeck \& Ruprecht, 2013.

Pakkala, Juha, Reinhard Müller, and Bas ter Haar Romeny. Evidence of Editing: Growth and Change of Texts in the Hebrew Bible. RBS 75. Atlanta, GA: SBL, 2013.

Pakkala, Juha, Marko Marttila, and Hanne von Weissenberg, eds. Changes in Scripture: Rewriting and Interpreting Authoritative Traditions in the Second Temple Period. BZAW 419. Berlin: de Gruyter, 2011.

Perrin, Andrew B. The Dynamics of Dream-Vision Revelation in the Aramaic Dead Sea Scrolls. JAJSup 19. Göttingen: Vandenhoeck \& Ruprecht, 2015.

Person, Raymond F., Jr. From Conversation to Oral Tradition: A Simplest Systematics for Oral Traditions. Routledge Studies in Rhetoric and Stylistics 10. New York: Routledge, 2016.

Person, Raymond F., Jr. "Education and the Transmission of Tradition." Pages 366-78 in The Wiley Blackwell Companion to Ancient Israel. Edited by Susan Niditch. West Sussex: John Wiley \& Sons, 2015.

Person, Raymond F., Jr., and Robert Rezetko, eds. Empirical Models Challenging Biblical Criticism. AIL 25. Atlanta, GA: SBL, 2016.

Puech, Émile. Qumran Grotte 4.XXII: Textes araméens, première partie: 4Q529-549. DJD 31. Oxford: Clarendon Press, 2001.

Stone, Michael, and Jonas Greenfield, "Levi Aramaic Document." Pages 1-72 in Qumran Cave 4.XVII: Parabiblical Texts, Part 3. Edited by George J. Brooke et al. DJD 22. Oxford: Clarendon Press, 1996.

Stuckenbruck, Loren T. The Book of Giants from Qumran: Texts, Translation and Commentary. TSAJ 63. Tübingen: Mohr Siebeck, 1997. 
Stuckenbruck, Loren T. “201. 4QEnoch ${ }^{\mathrm{a}}$, 203. 4QEnoch Giants"a ar, 206. 2-3. 4QEnoch ${ }^{\mathrm{f}}$ ar, 1Q23. 1QEnochGiants ${ }^{\mathrm{a}}$ ar, 1Q24. 1QEnochGiants ${ }^{\mathrm{b}}$ ? ar 2Q27. 2QEnochGiants ar, 6QpapGiants ar." Pages 3-94 in Qumran Cave 4.XXVI: Cryptic Texts, and Miscellanea, Part 1 . Edited by Stephen Pfann (cryptic texts), Philip Alexander et al. (miscellania). DJD 36. Oxford: Clarendon Press, 2000.

Tigchelaar, Eibert J. C. "Aramaic Texts from Qumran and the Authoritativeness of Hebrew Scriptures: Preliminary Observations." Pages $155^{-71}$ in Authoritative Scriptures in Ancient Judaism. Edited by Mladen Popović. JSJSup 141. Leiden: Brill, 2010.

Tigchelaar, Eibert J. C., and Florentino García Martínez, “208-209. 4QAstronomical Enoch $^{\mathrm{a}-\mathrm{b}}$ ar." Pages 95-171 in Qumran Cave 4.XXVI: Cryptic Texts, and Miscellanea, Part 1. Edited by Stephen Pfann (cryptic texts), Philip Alexander et al. (miscellania). DJD 36. Oxford: Clarendon Press, 2000. 